\title{
Religiusitas Dengan Gaya Hidup Hedonisme: Sebuah Gambaran Pada Mahasiswa Universitas Syiah Kuala
}

\author{
Ardilla Saputri, Risana Rachmatan \\ Program Studi Psikologi, Fakultas Kedokteran, Univesitas Syiah Kuala \\ email: risana.ridwan@gmail.com
}

\begin{abstract}
Abstrak
Gaya hidup hedonisme adalah pola hidup yang dinyatakan dalam aktivitas, minat, dan opini sebagai pencerminan dari keinginan untuk mencari kesenangan dalam hidupnya.Gaya hidup hedonis dapat menimbulkan dampak negatif salah satunya keinginan untuk terus berhura-hura. Penelitian ini bertujuan untuk mengetahui hubungan antara religiusitas dengan gaya hidup hedonisme pada mahasiswa S1 Universitas Syiah Kuala.. Sampel dalam penelitian ini adalah mahasiswa aktif S1 Unsyiah, berusia 18-22 tahun (masa remaja akhir) dengan menggunakan teknik random stratified sampling proportional. Subjek dalam penelitian ini berjumlah 377 orang. Pengumpulan data dilakukan dengan menggunakan skala religiusitas dan skala gaya hidup hedonisme yang peneliti susun sendiri. Hasil analisis data dengan teknik korelasi Spearman Product Moment mendapatkan koefisien korelasi ( $r$ ) sebesar $-0,40$ dengan nilai $p=0,00$ ( $p$ $<0,05)$. Hal ini menunjukkan bahwa terdapat hubungan negatif antara religiusitas dengan gaya hidup hedonisme pada mahasiswa S1 Unsyiah. Hasil analisa menunjukkan bahwa sebanyak $98.7 \%$ mahasiswa Unsyiah memiliki tingkat religiusitas yang tinggi, dan sebesar $78,4 \%$ memiliki tingkat hedonisme yang rendah.
\end{abstract}

Kata kunci: religiusitas, gaya hidup hedonisme, mahasiswa

\section{Religiosity and Hedonistic Lifestyle: An Overview at Syiah Kuala University (Unsyiah) Student}

\begin{abstract}
Hedonistic lifestyle expressed in activities, interests and opinions as a reflection of the desire to seek pleasure in life. Hedonistic lifestyle can negatively impact one wishes to continue the frivolous. This study aims to determine the relationship between religiosity and hedonistic lifestyle at Syiah Kuala University (Unsyiah) student. The sample in this research is the undergraduate Unsyiah active students, aged 18-22 years (late adolescence. The sampling technique were using proportional stratified random sampling. Subjects in this study amounted to 377 people. The data collection is done by using The Religiosity Scale and The Hedonistic Lifestyle Scale. Results of data analysis techniques using Spearman Product Moment Correlation, the correlation coefficient (r) of -0.40 with $p=0.00(p<0.05)$. This shows that there is a negative relationship between religiosity and hedonistic lifestyles on students S1 Unsyiah. The analysis shows that $98.7 \%$ of the students Unsyiah have high level of religiosity, and about $78.4 \%$ have a low level of hedonism.
\end{abstract}

Keywords: religiosity, hedonism lifestyle, undergraduate

\section{Pendahuluan}

Perubahan dewasa saat ini, berdampak pada berbagai kalangan. Salah satunya pada mahasiswa, yang dipengaruhi oleh adanya perkembangan teknologi yang pesat yang menimbulkan dampak munculnya globalisasi informasi, mode, serta semakin menjamurnya berbagai macam perangkat media massa dan elektronik, seperti televisi, internet, handphone dan alat-alat komunikasi lainnya yang ikut memengaruhi perubahan nilai sosial dan gaya hidup mahasiswa (Kunto,1999).

Mahasiswa pada umumnya digolongkan kedalam kelompok masa remaja akhir yang berada pada rentang usia 18-22 tahun dan merupakan masa transisi menuju ke fase dewasa (Santrock, 2003). Pada fase ini, mahasiswa seringkali menghadapi berbagai perubahan dan permasalahan karena merupakan masa penentuan identitas diri, dan pengembangan sikap realistis dan harapan. Hal ini diakibatkan oleh adanya ketidaksesuaian antara perkembangan fisik yang telah matang dengan perkembangan psikososialnya (Hurlock, 2009).

Salah satu bentuk perubahan perilaku yang tampak akibat globalisasi yang terjadi pada mahasiswa adalah munculnya perubahan gaya hidup. Gaya hidup merupakan pola manusia hidup dan menghabiskan waktu serta materi yang dimiliki (Engel, Blackwell, \& Miniard, 1994). Salah satu bentuk perubahan gaya hidup menurut Monks, Knoers dan Ha- 
ditomo (1998) yang terjadi pada mahasiswa adalah adanya hasrat atau keinginan agar penampilan, gaya tingkah laku, cara bersikap, dan lain-lainnya akan menarik perhatian orang lain, terutama kelompok teman sebaya, karena mahasiswa ingin diakui eksistensinya oleh lingkungan tempatnya berada. Hal ini tak jarang mengakibatkan para mahasiswa melakukan berbagai cara agar dapat memenuhi hasratnya tersebut. Salah satunya adalah mengunjungi berbagai pusat perbelanjaan, seperti mal, distro dan butik.

Penelitian yang dilakukan oleh Nielsen (dalam Halim, 2008) pada tahun 2005 menyebutkan bahwa 93\% konsumen yang berkunjung ke mal adalah remaja, yang menganggap bahwa belanja ke mal merupakan hiburan atau rekreasi. Hal ini telah menunjukkan bahwa berkunjung ke pusat perbelanjaan telah menjadi hal yang penting bagi mahasiswa, khususnya mahasiswa yang berusaha untuk menghindari steriotip kampungan. Fenomena ini menunjukkan adanya kecenderungan perilaku mahasiswa yang sekarang dihadapkan pada gaya hidup yang mengutamakan kesenangan semata sebagai tujuan hidup atau lebih dikenal dengan istilah hedonisme.

Menurut Salam (2002) prinsip gaya hidup hedonis menganggap bahwa segala sesuatu akan dianggap baik jika hal tersebut telah sesuai dengan kesenangan yang akan diperoleh. Pengertian gaya hidup hedonis lainnya juga diungkapkan oleh Wells dan Tigert (dalam Engel, Blackwell, \& Miniard 1994) yang menjelaskan bahwa gaya hidup hedonis adalah pola hidup seseorang sebagai proses penggunaan uang dan waktu yang dimiliki yang dinyatakan dalam aktivitas, minat, dan pendapat (opini) yang bersangkutan. Hal tersebut diwujudkan dalam hal tertentu seperti fashion, makanan, benda-benda mewah, tempat berkumpul dan selalu ingin menjadi pusat perhatian. Orang-orang yang menganut gaya hidup hedonis lebih sering manghabiskan waktu diluar rumah seperti mal dan kafe.

Sekarang ini di Aceh khususnya Banda Aceh, hal-hal yang berhubungan dengan pemenuhan kebutuhan akan gaya hidup hedonis sangat mudah ditemukan. Hasil observasi yang peneliti lakukan menunjukkan bahwa fasilitas dan tempat hiburan yang saat ini mulai banyak muncul di Banda Aceh seolah-olah menjadi sarana yang menarik bagi para mahasiswa untuk mengembangkan gaya hidup hedonisnya, misalnya mulai menjamurnya kafe-kafe, mal, butik dan distro di berbagai sudut kota Banda Aceh. Bahkan barang-barang bermerek seperti Channel, Guest, Prada, Hermes, Vincci dan lain sebagainya sudah sangat mudah ditemui di Banda Aceh (Observasi personal, 7 November 2013).
Aceh sebagai daerah yang terkenal sebagai Serambi Mekah, memiliki pengamalan syariat Islam yang lebih kental apabila dibandingkan dengan daerah-daerah lainnya (Alyasa, 2006). Berdasarkan keistimewaan ini, masyarakat Aceh secara sosial memiliki kewenangan untuk menegakkan nilai-nilai keagamaan secara komperhensif (Dwi, 2013).

Beberapa ahli sepakat bahwa religiusitas dapat berpengaruh terhadap tabiat personal dan sosial remaja (Raba, 2001), dan juga sebagai pendukung pembentukan emosi melalui peningkatan harga diri (Al-Qardhawi, 1977), dan kebahagiaan dalam hidup. Di dunia Barat, istilah religiusitas hanya dibatasi pada lingkup praktek keagamaan, ritual dan perilaku prososialnya saja. Namun, di Indonesia khususnya di Aceh, religiusitas merupakan sesuatu yang melandasi bagaimana cara seseorang menjalani hidupnya (Dwi, 2013). Di Aceh, Islam merupakan agama yang mayoritas. Religiusitas dalam agama Islam dijadikan sebagai salah satu dasar dalam tumbuh kembang seseorang (Zullig,Ward \& Horn, 2006).

Pembahasan tentang gaya hidup hedonis yang sangat mengedepankan kesenangan, memunculkan anggapan bahwa gaya hidup tersebut berorientasi pada sesuatu yang bersifat berlebih-lebihan, sedangkan dari sisi religiusitas gaya hidup hedonis tidak dibenarkan karena menurut Chatijah dan Purwadi (2007) salah satu penyebab meningkatnya gaya hidup hedonis pada usia remaja adalah karena merosotnya iman. Apabila seseorang mengalami kemerosotan iman, maka cenderung melakukan hal-hal yang dilarang oleh agama. Salah satu larangan agama adalah bersikap berlebih-lebihan atau bersikap boros.

Menurut Glock dan Stark (dalam Ancok \& Suroso, 2011), pada dasarnya secara harfiah seseorang yang religius akan selalu berusaha untuk berbuat kebaikan, tidak hanya untuk dirinya sendiri tetapi juga untuk orang lain. Religiusitas adalah suatu simbol sistem keyakinan, nilai, dan perilaku yang memusatkan berbagai persoalan-persoalan duniawi yang keseluruhan maknanya disimpulkan dalam suatu keyakinan hakiki.

Glock dan Strak (dalam Ancok \& Suroso, 2011) mengemukakan ada beberapa dimensi dalam religiusitas yaitu keyakinan, ritual, pengamalan, pengetahuan dan pengalaman. Berdasarkan dimensi keyakinan, orang dengan tingkat keyakinan religiusitas yang tinggi akan berperilaku konsekuen dengan ajaran agamanya dalam bersosial dengan masyarakat. Namun disamping itu, hasil penelitian Ernest Harms (dalam Jalaluddin, 2012) menunjukkan bahwa remaja lebih mementingkan kesenangan pribadinya daripada masalah religiusitas. 
Dimensi religiusitas lainnya menurut Glock dan Stark (dalam Ancok \& Suroso, 2004), yang dapat memengaruhi gaya hidup hedonis adalah dimensi pengamalan. Dimensi ini membahas tentang sejauh mana perilaku individu dimotivasi oleh ajaran agamanya didalam kehidupan sosial, sehingga apabila mahasiswa memiliki pengamalan agama yang baik, maka mahasiswa tersebut akan menunjukkan perilaku sosial sesuai dengan ajaran agamanya.

Hal tersebut didukung oleh penelitian yang dilakukan Rocca (dalam Mulia, 2010) yang menunjukkan bahwa seseorang yang memiliki religiusitas yang tinggi lebih berkomitmen dengan ajaran agamanya sehingga relatif memiliki keinginan yang rendah untuk mengikuti gaya hidup yang hanya mementingkan kesenangan. Berdasarkan pernyataan tersebut terlihat jelas bagaimana religiusitas menjadi salah satu aspek yang dapat menurunkan tingkat gaya hidup hedonis.

Berdasarkan penjelasan tersebut, maka salah satu faktor yang dapat mengendalikan gaya hidup hedonis mahasiswa adalah pengamalan nilai-nilai religiusitas, yang dapat diperoleh mahasiswa dari keluarga maupun instansi pendidikan. Religiusitas seharusnya dapat mengontrol gaya hidup hedonis pada mahasiswa (Hartini, 2011).

\section{Metode}

\section{Partisipan}

Penelitian ini merupakan penelitian yang menggunakan pendekatan kuantitatif korelasional, dimana populasi dari penelitian ini adalah seluruh mahasiswa Universitas Syiah Kuala dari 11 fakultas yang ada. Pengambilan sampel dilakukan dengan cara probability sampling yaitu teknik random stratified sampling proportional. Adapun teknik ini digunakan pada suatu populasi yang terbagi atas beberapa subkelompok dan dari masingmasing subkelompok diambil sampel-sampel terpisah. Banyaknya subjek dalam setiap subkelompok harus diketahui perbandingannya terlebih dahulu.Kemudian ditentukan presentase besarnya sampel dari keseluruhan populasi (Azwar, 2009).

Jumlah seluruh mahasiswa S1 Unsyiah adalah sebanyak 22.213 orang. Sampel dalam penelitian ini diambil menggunakan pedoman tabel Krejcie dan Morgan (1970) dengan tingkat kesalahan $5 \%$ dan tingkat kepercayaan $95 \%$. Menurut tabel Krejcie dan Morgan jumlah sampel dalam penelitian ini adalah sebanyak 377 orang.

\section{Alat Ukur}

Pengumpulan data penelitian dilakukan dengan menggunakan dua skala, yaitu (a) Skala Gaya Hidup Hedonisme yang digu- nakan untuk mengukur variabel gaya hidup hedonisme yang disusun sendiri oleh peneliti berdasarkan kriteria gaya hidup hedonisme yang dikemukakan oleh Well dan Tigert (dalam Engel, Blackwell, \& Miniard 1994). Skala ini terdiri dari 4 pilihan jawaban yaitu dari Sangat Tidak Sesuai (STS), Tidak Seuai (TS), Sesuai (S), dan Sangat Sesuai (SS), (b) Skala Religiusitas yang digunakan untuk mengukur variabel religiusitas yang disusun sendiri oleh peneliti berdasarkan dimensi religiusitas yang dikemukakan oleh Glock dan Stark (dalam Ancok dan Suroso, 2011). Skala tersebut terdiri dari empat pilihan jawaban yaitu dari Sangat Tidak Sesuai (STS), Tidak Sesuai (TS), Sesuai (S), dan Sangat Sesuai (SS),. Adapun salah satu contoh item dari Skala Hedonisme adalah "Uang yang saya miliki saya habiskan untuk bersenang-senang." Salah satu item untuk Skala Religiusitas adalah "Rasul diutus untuk menyempurnakan akhlak manusia."

Kedua skala tersebut mengandung dua jenis pernyataan, yaitu pernyataan favourable (mendukung atribut ukur) dan unfavourable (tidak mendukung atribut ukur). Skor penilaian bergerak dari 1 sampai 4 , apabila pernyataan favourable maka STS/TP bernilai 1, TS/P bernilai 2, S/P bernilai $3, S S / S S$ bernilai 4 , namun untuk pernyataan unfavourable penilaian sebaliknya dari pernyataan favourable.

\section{Reliabilitas}

Sekaran (dalam Oktavia, 2013) menyatakan ada beberapa batasan dalam menilai koefisien reliabilitas. Koefisien reliabilitas yang kurang dari 0,6 menunjukkan bahwa reliabilitas skala kurang baik, sedangkan koefisien korelasi 0,7 menunjukkan bahwa reliabilitas skala dapat diterima dan apabila koefisien reliabilitas berada di atas 0,8 menujukkan bahwa reliabilitas skala tersebut baik. Skala Gaya Hidup Hedonis yang diberikan untuk uji coba terdiri dari 30 pernyataan, setelah dilakukan uji reliabilitas pernyataan diketahui koefisien reliabilitas alpha sebesar 0,91 . Selanjutnya nilai koefisien reliabilitas alpha skala Gaya Hidup Hedonis bertambah menjadi 0,92 dikarenakan item yang gugur dihilangkan dalam skala yang digunakan. Hal ini menunjukkan bahwa Skala Gaya Hidup Hedonis ini baik dan reliabel.

Skala Religiusitas yang diberikan untuk uji coba terdiri dari 40 pernyataan, setelah dilakukan uji reliabilitas pernyataan diketahui koefisien reliabilitas alpha sebesar 0,86 . Selanjutnya nilai koefisien reliabilitas alpha skala Religiusitas bertambah menjadi 0,90 dikarenakan item yang gugur dihilangkan dalam skala yang digunakan. Hal ini menunjukkan bahwa Skala Religiusitas ini baik dan reliabel. 


\section{Validitas}

Validasi merupakan suatu ukuran yang menunjukkan tingkat kevalidan atau kesahihan suatu instrument. Validitas yang digunakan adalah validitas konten yang diperoleh dari expert review yang telah disetujui oleh pembimbing, dengan kualifikasi berpendidikan minimal S2 serta menguasai bidang psikologi sosial, psikologi perkembangan, psikologi lintas budaya dan psikologi Islam.

Selanjutnya, akan dihitung daya beda pernyataan dengan bantuan program SPSS versi 16.0. pernyataan-pernyataan yang digunakan dalam penelitian ini adalah pernyataan-pernyataan yang memiliki koefisien total antara pernyataan sebesar 0.30 . Hal ini mengikuti pendapat Azwar (2009) yang menyatakan, bahwa kriteria pemilihan penyataan berdasarkan korelasi penyataan total biasanya menggunakan batasan rix $\geq 0.30$.

\section{Teknik Analisis Data}

Data yang diperoleh dari penelitian diolah menggunakan teknik analisis uji korelasi Spearman, dikarenakan salah satu variabel penelitian memiliki distribusi data yang tidak normal. Keseluruhan analisis data dilakukan dengan menggunakan Aplikasi Komputer.

\section{Hasil}

Deskripsi Data

Data demografi sampel yang diperoleh dari hasil penelitian dapat dilihat pada tabel dibawah ini:

Tabel 1 Data Demografi Sampel Penelitian

\begin{tabular}{|c|c|c|c|c|c|}
\hline No. & Deskripsi Sampel & Kategori & Jumlah & Presentase & Total \\
\hline \multirow[t]{2}{*}{1.} & \multirow[t]{2}{*}{ Jenis Kelamin } & Laki-Laki & 142 orang & $37,7 \%$ & \multirow[t]{2}{*}{$100 \%$} \\
\hline & & Perempuan & 235 orang & $62,3 \%$ & \\
\hline 2. & Tempat Tinggal & $\begin{array}{l}\text { Rumah Orang Tua } \\
\text { Kos } \\
\text { Asrama } \\
\text { Tempat Lain }\end{array}$ & $\begin{array}{l}183 \text { orang } \\
168 \text { orang } \\
9 \text { orang } \\
17 \text { orang }\end{array}$ & $\begin{array}{l}48,5 \% \\
44,6 \% \\
2,9 \% \\
4,5 \%\end{array}$ & $100 \%$ \\
\hline 3. & $\begin{array}{l}\text { Kendaraan yang } \\
\text { digunakan untuk } \\
\text { kuliah }\end{array}$ & $\begin{array}{l}\text { Mobil } \\
\text { Motor } \\
\text { Sepeda } \\
\text { Angkutan Umum }\end{array}$ & $\begin{array}{l}39 \text { orang } \\
299 \text { orang } \\
6 \text { orang } \\
33 \text { orang }\end{array}$ & $\begin{array}{l}10,3 \% \\
79,3 \% \\
1,6 \% \\
8,75 \%\end{array}$ & $100 \%$ \\
\hline 4. & $\begin{array}{l}\text { Tempat yang lebih } \\
\text { sering di kunjungi } \\
\text { untuk mengisi waktu }\end{array}$ & $\begin{array}{l}\text { Mall } \\
\text { Kafe/Warung Kopi } \\
\text { Tempat Rekreasi } \\
\text { Tempat Lain }\end{array}$ & $\begin{array}{l}65 \text { orang } \\
212 \text { orang } \\
31 \text { orang } \\
69 \text { orang }\end{array}$ & $\begin{array}{l}17,2 \% \\
56,2 \% \\
8,2 \% \\
18,4 \%\end{array}$ & $100 \%$ \\
\hline \multirow[t]{5}{*}{5.} & \multirow[t]{5}{*}{ Fakultas } & \multirow{5}{*}{$\begin{array}{l}\text { Fak. Ekonomi } \\
\text { Fak. Hukum } \\
\text { Fak. Pertanian } \\
\text { Fak. Kedokteran } \\
\text { Hewan } \\
\text { Fak. Teknik } \\
\text { Fak. Kedokteran } \\
\text { Fak. MIPA } \\
\text { Fak. Ilmu Sosial } \\
\text { dan Ilmu Politik } \\
\text { Koord. Kelautan } \\
\text { dan Perikanan } \\
\text { Fak. Keguruan dan } \\
\text { Ilmu Pendidikan }\end{array}$} & $\begin{array}{l}32 \text { orang } \\
30 \text { orang } \\
32 \text { orang }\end{array}$ & $\begin{array}{l}8,5 \% \\
8 \% \\
8,5 \%\end{array}$ & \multirow[t]{5}{*}{$100 \%$} \\
\hline & & & $\begin{array}{l}12 \text { orang } \\
48 \text { orang } \\
42 \text { orang } \\
18 \text { orang }\end{array}$ & $\begin{array}{l}3,2 \% \\
12,7 \% \\
11,1 \% \\
5 \%\end{array}$ & \\
\hline & & & 28 orang & $7,4 \%$ & \\
\hline & & & 11 orang & $2,9 \%$ & \\
\hline & & & 124 orang & $32,6 \%$ & \\
\hline \multirow[t]{3}{*}{6.} & \multirow{3}{*}{$\begin{array}{l}\text { Rata-rata Uang } \\
\text { Saku Perbulan }\end{array}$} & \multirow{3}{*}{$\begin{array}{l}<\operatorname{Rp} 500.000 \\
\operatorname{Rp} 500000- \\
\operatorname{Rp} 750000 \\
\operatorname{Rp} 750000- \\
\operatorname{Rp} 1000000\end{array}$} & 59 orang & $15,6 \%$ & \multirow[t]{3}{*}{$100 \%$} \\
\hline & & & 66 orang & $17,5 \%$ & \\
\hline & & & 153 orang & $40,6 \%$ & \\
\hline
\end{tabular}




\begin{tabular}{|c|c|c|c|c|c|}
\hline & & $\begin{array}{l}\operatorname{Rp} 1000000- \\
\operatorname{Rp} 1500000 \\
>\operatorname{Rp} 1500000\end{array}$ & $\begin{array}{l}73 \text { orang } \\
26 \text { orang }\end{array}$ & $\begin{array}{l}19,4 \% \\
6,9 \%\end{array}$ & \\
\hline \multirow[t]{4}{*}{7.} & \multirow{4}{*}{$\begin{array}{l}\text { Rata-Rata } \\
\text { Pengeluaran } \\
\text { Perbulan }\end{array}$} & $<\operatorname{Rp} 500.000$ & 52 orang & $13,8 \%$ & \multirow[t]{4}{*}{$100 \%$} \\
\hline & & $\operatorname{Rp} 750000$ & 95 orang & $25,2 \%$ & \\
\hline & & $\begin{array}{l}\operatorname{Rp} 1000000 \\
\operatorname{Rp} 1000000-\end{array}$ & 142 orang & $37,7 \%$ & \\
\hline & & $\begin{array}{l}\operatorname{Rp} 1500000 \\
>\operatorname{Rp} 1500000\end{array}$ & $\begin{array}{l}64 \text { orang } \\
24 \text { orang }\end{array}$ & $\begin{array}{l}16,9 \% \\
6,4 \%\end{array}$ & \\
\hline
\end{tabular}

Berdasarkan tabel diatas dapat dilihat bahwa jumlah sampel penelitian yang berjenis kelamin perempuan sebanyak $62,3 \%$ lebih besar dari pada jumlah sampel penelitian dengan jenis kelamin laki-laki yaitu sebanyak $37,7 \%$. Kemudian dapat dilihat pula bahwa sampel penelitian yang tinggal di rumah orang tua yaitu sebesar $48,5 \%$, lebih besar dibandingkan sampel penelitian yang tinggal di kos yaitu sebesar $44,6 \%$, asrama $2,9 \%$ dan tempat lainnya sebesar $4,5 \%$. Selanjutnya sampel penelitian yang menggunakan motor sebagai kendaraan untuk kuliah yaitu sebesar $79,3 \%$ lebih besar dibandingkan yang menggunakan mobil yaitu sebesar $10,3 \%$, sepeda sebesar $1,6 \%$ dan angkutan umum sebesar $8,75 \%$.

Data demografis lainnya juga menunjukkan bahwa tempat yang lebih sering dikunjungi untuk mengisi waktu adalah kafe atau warung kopi dengan jumlah persentase sebesar $56,2 \%$, lebih besar dari persentase mengunjungi mal sebanyak $17,2 \%$, tempat rekreasi $8,2 \%$ dan tempat lainnya sebesar $18,4 \%$.

Selanjutnya dari data demografis juga terlihat bahwa, rata-rata uang saku perbulan yang diperoleh sampel yaitu sebesar $40,6 \%$ berada diantara Rp 750.000 sampai dengan Rp 1.000.000, kemudian diikuti oleh sampel yang menerima uang saku sebesar Rp 1.000.000 - Rp 1.500.000 sebanyak 19,4\%, menerima uang saku perbulan Rp 500.000 - Rp 750.000 sebanyak $17,5 \%$, kurang dari Rp 500000 sekitar $15,6 \%$ dan $6,9 \%$ sampel menerima uang saku lebih dari Rp 1.500.000.

Selain itu, peneliti juga menanyakan tentang rata-rata pengeluaran bulanan dari sampel penelitian. Berdasarkan hasil penelitian didapatkan bahwa sebanyak $37,7 \%$ mengeluarkan $\mathrm{Rp} 750.000$ sampai dengan Rp 1.000.000 setiap bulannya, $25,5 \%$ memiliki pengeluaran sebesar Rp 500.000 sampai dengan $\operatorname{Rp} 750.000$, diikuti $16,9 \%$ memiliki pengeluaran sebesar Rp 1.000.000 sampai dengan $\mathrm{Rp} 1.500 .000$, kemudian $13,8 \%$ memiliki pengeluaran kurang dari Rp 500.000 dan diakhiri dengan $6,4 \%$ memiliki pengeluaran lebih besar dari Rp 1.500.000.

\section{Uji Asumsi}

Penggunaan uji asumsi pada penelitian menentukan uji statistik parametrik atau non parametrik yang akan digunakan untuk mengetahui hubungan antara dua variabel. Uji asumsi meliputi:

\section{Uji Normalitas}

Hasil uji normalitas yang dilakukan pada 377 sampel penelitian menunjukkan pada variabel gaya hidup hedonisme diperoleh hasil (K-S Z $=1,05, p=0,21>$ $0,05)$ artinya variabel gaya hidup hedonisme berdistribusi normal dengan $(p>0,05)$. Hasil uji normalitas variabel religiusitas diketahui bahwa nilai (K-S Z = 1,89, $\mathrm{p}=$ $0,01>0,05)$ artinya variabel religiusitas berdistribusi tidak normal dengan ( $<<0,05)$.

\section{Uji Linearitas}

Hasil uji linearitas yang dilakukan dari 377 sampel penelitian melalui ANOVA test for linearity menunjukkan nilai signifikansi pada linearitas sebesar 0,00 . Nilai signifikansi yang kurang dari $0,05(p=0,00<0,05)$ memperlihatkan hubungan yang linear antara variabel gaya hidup hedonis dengan religiusitas.

\section{Uji Hipotesis}

Peneliti melakukan uji hipotesis dengan menggunakan analisis korelasi Spearman Product Moment Correlation. Analisis ini digunakan karena salah satu data dari variabel penelitian berdistribusi tidak normal. Metode ini digunakan untuk membuktikan hubungan antara religiusitas dengan gaya hidup hedonisme pada mahasiswa Unsyiah. Hasil analisis menunjukkan koefisien korelasi sebesar $-0,407$. Artinya terdapat hubungan yang negatif antara religiusitas dengan gaya hidup hedonisme. Hubungan tersebut mengartikan bahwa jika nilai religiusitas semakin tinggi maka akan semakin rendah pula gaya hidup hedonisme pada mahasiswa Unsyiah. Signifikansi hubungan antara kedua variabel ditunjukkan dengan koefisien $r=-0,407, p=0,00<0,05$. Hasil koefisien terhitung $=-0,407$ dan nilai taraf signifikansi sebesar 0,00 
( $p<0,05)$, menunjukkan bahwa hipotesis penelitian diterima yaitu ada hubungan negatif antara religiusitas dengan gaya hidup hedonisme pada mahasiswa Unsyiah. Analisis korelasi dimensi religi- usitas dilakukan untuk melihat hubungan dengan setiap dimensi dari variabel gaya hidup hedonisme. Berikut hasil analisis korelasi dimensi yang dilakukan:

Tabel 2. Korelasi dimensi religiusitas dengan variable gaya hidup hedonism

\begin{tabular}{lll}
\hline Dimensi variabel religiusitas & Korelasi & Signifikansi \\
\hline Keyakinan & $-0,192$ & $\mathrm{p}=0,000$ \\
Praktik keagamaan & $-0,435$ & $\mathrm{p}=0,000$ \\
Pengalaman & $-0,226$ & $\mathrm{p}=0,000$ \\
Pengetahuan Keagamaan & $-0,439$ & $\mathrm{p}=0,000$ \\
Pengamalan & $-0,162$ & $\mathrm{p}=0,002$ \\
\hline
\end{tabular}

Berdasarkan tabel 2 semua dimensi religiusitas memiliki signifikansi $<0.01$ terhadap gaya hidup hedonisme. Namun dimensi yang menunjukkan korelasi terbesar adalah pengetahuan keagamaan dengan nilai rhitung $=-0,439$ dan memiliki taraf signifikansi sebesar $0,00(p<0,05)$. Dengan kata lain, dimensi religiusitas yang paling memiliki hubungan erat dengan gaya hidup hedonis adalah dimensi pengetahuan keagamaan.

\section{Pembahasan}

Berdasarkan perhitungan statistik yang telah dilakukan, dapat dilihat dari hasil rhitung $=-0,407$ dan nilai taraf signifikansi sebesar $0,00(p<0,05)$, sehingga dapat dikatakan bahwa hipotesis penelitian diterima. Hasil tersebut menunjukkan bahwa religiusitas memiliki hubungan yang negatif dengan gaya hidup hedonisme pada mahasiswa Unsyiah. Semakin tinggi tingkat religiusitas seseorang, maka semakin rendah pula gaya hidup hedonismenya. Begitu pula sebaliknya, semakin rendah tingkat religiusitas seseorang maka semakin tinggi pula gaya hidup hedonismenya.

Terbuktinya hipotesis penelitian ini didukung oleh penelitian yang dilakukan Mulia (2010) hubungan tingkat religiusitas dan kecenderungan hedonisme pada remaja akhir. Penelitian tersebut dilakukan pada kelompok remaja akhir yang berada di Universitas Gunadharma. Penelitian tersebut menjelaskan bahwa seseorang yang memiliki religiusitas yang tinggi lebih berkomitmen terhadap ajaran agamanya dan relatif memiliki kepentingan yang rendah untuk mengikuti hasrat hedonisme.

Selain itu, hasil penelitian ini juga didukung oleh penelitian yang dilakukan oleh Milfont, dkk (2008). Hasil penelitian tersebut menunjukkan bahwa perilaku hedonis memiliki hubungan negatif dengan religiusitas. Hal tersebut mengindikasikan bahwa gaya hidup remaja dipengaruhi oleh religiusitas yang memberi pengaruh penting terhadap perkembangan remaja yang positif.
Kemudian penelitian yang dilakukan oleh Chatijah dan Purwadi (2007) pada 213 siswi kelas XI SMA 3 Muhammadiyah Yogjakarta yang menemukan bahwa religiusitas memiliki hubungan yang signifikan dengan perilaku konsumtif. Penelitian tersebut menjelaskan bahwa individu yang memiliki tingkat religiusitas yang tinggi cenderung diikuti dengan rendahnya sikap konsumtif dan begitu pula sebaliknya.Seseorang yang memiliki tingkat religiusitas yang tinggi akan berperilaku sesuai dengan ajaran agamanya. Hasil penelitian menunjukkan bahwa tingkat religiusitas mahasiswa Unsyiah yang berada pada kategori tinggi adalah sebanyak 372 mahasiswa $(98,7 \%)$ dengan nilairatarata atau mean sebesar 91,3. Mulia (2010) dalam penelitiannya mengungkapkan bahwa individu dengan religiusitas tinggi memiliki keyakinan untuk mengamalkan nilai-nilai religi yang dianutnya, sehingga cenderung berperilaku sesuai dengan nilai-nilai yang dianutnya tersebut. Thouless (2000) menyatakan bahwa mahasiswa yang religiusitasnya rendah akan cenderung lebih mudah dipengaruhi oleh perilaku menyimpang dari pada remaja yang memiliki religiusitas tinggi.

Glock dan Stark (dalam Ancok dan Suroso, 2011) memaparkan 5 dimensi yang memengaruhi religuistas. Religiusitas yang tinggi tercermin dari 5 dimensi religiusitas yang dapat mengontrol gaya hidup hedonisme seseorang. Hasil penelitian menunjukkan bahwa ke lima dimensi religiusitas tersebut memiliki hubungan yang signifikan dengan gaya hidup hedonis. Salah satu dimensi yang memiliki hubungan signifikan dengan gaya hidup hedonisme adalah dimensi pengetahuan agama. Dimensi ini merupakan dimensi yang memiliki hubungan yang paling signifikan terhadap gaya hidup hedonisme. Muhaimin dkk. (dalam Hasan, 2006) mengatakan bahwa kehidupan beragama didasarkan pada pengetahuan dan pemahaman keagamaan seseorang. Hal tersebut dapat menjadi pengendali, pengarah serta kontrol terhadap perkembangan sistem bu- 
daya dan peradaban modern atau sekurangkurangnya mempunyai efek pengereman kecenderungan dan sifat dasar masyarakat modern yang bebas tanpa kendali. Pengetahuan yang ini didapat dari kitab suci maupun sumber-sumber lainnya. Mahasiswa dengan pengetahuan keagamaan yang tinggi akan cenderung memiliki kontrol dan memahami tentang makna dilarangnya manusia untuk bersikap boros dan berlebih-lebihan.

Sejalan dengan penjelasan dimensi religiusitas diatas maka semakin tinggi religiusitas, akan semakin rendah gaya hidup hedonisnya. Hal ini sesuai dengan hasil penelitian yang dilakukan, dimana hasil penelitian menunjukkan bahwa gaya hidup hedonis pada mahasiswa Unsyiah berada pada kategori rendah. Sebanyak 282 mahasiswa $(78,4 \%)$ memiliki mean 56,6. Kecenderungan gaya hidup hedonis pada kategori rendah menunjukkan bahwa mahasiswa tidak memiliki gaya hidup hedonis pada tingkat yang mengkhawatirkan. Walau pada kenyataannya menjamurnya tempat-tempat hiburan atau berbagai kafe di Banda Aceh atau disekitar kampus. Hal tersebut didukung hasil data demografis menunjukkan tempat yang paling sering dikunjungi oleh mahasiswa untuk mengisi waktunya adalah kafe atau warung kopi. Sesuai dengan hasi penelitian ini, rendahnya gaya hidup hedonis pada mahasiswa Unsyiah salah satunya dipengaruhi oleh tingkat religiusitas yang dimiliki oleh mahasiswa Unsyiah yang kebanyakan berada pada kategori tinggi.

Hal yang ditemukan pada penelitian ini adalah rendahnya gaya hidup hedonis pada mahasiswa Unsyiah, hal ini dapat dapat dijelaskan salah satunya karena dipengaruhi oleh kondisi bahwa subjek kebanyakan adalah remaja yang belum memiliki penghasilan sendiri, atau masih meraba mengenai kehidupan sosial (Hurlock, 2009). Selain itu, hal tersebut dapat pula terjadi karena adanya kesadaran dari mahasiswa mengenai pentingnya mendahulukan nilai keagamaan dari pada keinginan bersenang-senang (Dwi, 2013). Kondisi tersebut sesuai dengan penelitian Coleman (dalam Sarwono, 2006) yang menyatakan bahwa ada beberapa kelompok remaja yang menekankan pentingnya nilainilai religiusitas daripada budaya anak muda yang mengacu pada kegiatan bersenangsenang. Kenyataan tersebut dipengaruhi oleh faktor lingkungan tempat remaja tersebut berada, salah satunya adalah keluarga. Mahasiswa yang berada dilingkungan keluarga yang menekankan pentingnya nilai keagamaan cenderung memiliki kesadaran untuk menghindari perilaku yang menyimpang salah satunya adalah keinginan untuk berhura-hura. Analisis data penelitian juga ingin mengetahui besar sumbangan efektif religiusitas terhadap tingkat gaya hidup hedon- isme. Hasil analisis menunjukkan bahwa variabel religiusitas memberi sumbangan efektif sebesar $14,6 \%$ terhadap tingkat gaya hidup hedonisme, sumbangan efektif tersebut menjelaskan dampak rendahnya gaya hidup hedonis mahasiswa yang disebabkan faktor religiusitas yang tinggi, sedangkan sisanya sebesar $85,5 \%$ dipengaruhi oleh faktor yang lain, sehingga dapat dikatakan variabel religiusitas bukanlah satu-satunya faktor yang memengaruhi sikap gaya hidup hedonisme.

Menurut Wijokongko (dalam Martha dan Imam, 2008), faktor-faktor lain yang dapat memengaruhi gaya hidup hedonisme diantaranya adalah harga diri, motif dan kepribadian, kepercayaan diri, kelas sosial, keluarga, kebudayaan, pengaruh kelompok sebaya dan kondisi lingkungan.

Penelitian ini tidak luput dari adanya kendala dan keterbatasan serta kekurangan. Keterbatasan dalam penelitian ini adalah dari segi metode penelitian. Penelitian ini menggunakan metode kuantitatif yang hanya menggunakan sebagian kecil populasi sebagai sampel penelitian dan men-generalisasikan hasilnya terhadap seluruh populasi. Dengan metode ini juga penelitian hanya berfokus pada dua variabel yang akan diukur, sehingga tidak mendapatkan informasi mengenai variabel lain yang juga memengaruhi hasil penelitian ini. Selain itu, keterbatasan referensi menghambat peneliti untuk mengkaji lebih dalam mengenai hubungan kedua variabel.

\section{Kesimpulan}

Hasil penelitian menunjukkan bahwa terdapat hubungan negatif antara religiusitas dengan gaya hidup hedonisme pada mahasiswa Unsyiah. Hal ini menjelaskan bahwa semakin tinggi religiusitas mahasiswa maka akan semakin rendah pula gaya hidup hedonismenya. Begitu juga sebaliknya, semakin rendah religiusitas mahasiswa maka semakin tinggi pula gaya hidup hedonismenya. Penelitian ini memperlihatkan bahwa mahasiswa Unsyiah memiliki tingkat religiusitas yang tinggi dan memiliki tingkat gaya hidup hedonisme yang rendah.

Saran kepada mahasiswa Unsyiah yaitu agar mahasiswa dapat mengisi waktu luang dengan memperbanyak melakukan kegiatan yang positif seperti, mengikuti kajian-kajian keagamaan yang diadakan di kampus maupun di tempat-tempat lainnya. Selain itu, mahasiswa juga diharapkan untuk lebih meningkatkan kegiatan yang berhubungan dengan dunia kampus, seperti kegiatan organisasi-organisasi kampus dan mengurangi kegiatan yang hanya menyia-nyiakan waktu dan uang. Selanjutnya yaitu saran bagi keluarga dan lingkungan sekitar adalah diharapkan mau memupuk sikap religius pada maha- 
siswa, dan mengontrol gaya hidup hedonisme pada mahasiswa dengan cara tidak memberikan kebebasan yang berlebihan kepada mahasiswa serta mengingatkan dan mengajak mahasiswa untuk mengikuti kegiatan kegamaan. Saran yang terakhir adalah bagi peneliti selanjutnya yaitu agar terus mencari informasi terkini atau teori terbaru karena gaya hidup hedonisme merupakan suatu fenomena yang terus mengalami perkembangan dan dapat mempertimbangkan variabel lainnya yang berpengaruh terhadap gaya hidup hedonisme, seperti kebudayaan, nilai sosial, demografis, status sosial, kelompok referensi, rumah tangga, persepsi, memori, motif dan kepribadian serta konsep diri. Selain itu, peneliti lain juga dapat meneliti pada subjek penelitian dengan kriteria yang berbeda.

\section{Daftar Pustaka}

Alyasa, A.B. (2006). Syariat Islam di Provinsi Nanggroe Aceh Darus salam-paradigma, kebijakan, dan kegiatan. Dinas Syariat Islam. Banda Aceh

American Psychology Association. (2010). Publication Manual of The American Psychologiacal Association (6th edition). Washington, DC: American Psychology Association

Ancok, D., \& Suroso. (2011). Psikologi Islami. Yogyakarta : Pustaka Pelajar

Azwar, S. (2009). Dasar-Dasar Psikometri. Yogyakarta: Pustaka Pelajar.

Azwar, S. (2012). Penyusunan skala psikologi. Yogyakarta: Pustaka Pelajar.

Chatijah, S. \& Purwadi. (2007). Hubungan Religiusitas Dengan Sikap Konsumtif Pada Remaja. Humanitas. Volume 4 No. 2. Yogyakarta.

Dorojatun, Z. (1998). Psikologi Agama. Jakarta: PT.Raja Grafindo Persada

Dwi S, H. (2013, December 15). Wisata kuliner warung kopi di Aceh. Surat Kabar Antara News. Diakses pada tanggal 4 Mei 2014 dari h t t p : / / w w w. antaranews. com/berita/409604/wisatakuliner-warung-kopi-di-aceh

Engel, J.F., Blackwell R.D., Miniard, P.W. (1994). Perilaku Konsumen : Jilid 1. Alih Bahasa: Budijanto. Jakarta: Binarupa Aksara. (Edisi keenam)

Halim, D. K. (2008). Psikologi Lingkungan Perkotaan. Jakarta: $S$ i $n$ a $r$ Grafika Offset.

Hartini, N. (2011). Remaja Nanggroe Aceh Darussalam Pasca Tsunami. Psikologi Klinis dan Kesehatan Mental Fakultas Psikologi Universitas Airlangga. Diakses dari http://journal. unair.ac.id/filerPDF/06_Rema- ja $\% 20 \mathrm{Nangroe} \% 20 \mathrm{Aceh} \% 20$ Darussalam\%20Pasca\%20Tsuna $\mathrm{m}$ i $\% 2020010$, \% 200 d e vita $\% 20$ editan $\% 20$ niken $\% 20$ mda.pdf pāda tanggal 4 Mei $20 \overline{14}$

Hasan,A.B.P. (2006).PsikologiPerkembangan Islami. Jakarta: Raja Grafindo Persada.

Hurlock, E. (2009). Psikologi Perkembangan Suatu Pendekatan Sepanjang Rentang Kehidupan Edisi Kelima. Alih Bahasa : Istiwadayanti. Jakarta : Erlangga

Jalaluddin. (2012). Psikologi Agama. Jakarta: Rajawali Pers.

Krejcie, R.V., \& Morgan, D.W. (1970). Determining Sample Size for Research Activities. Educational and psychological measurement. 30. Di akses dari http://opa.up rrp.edu/InvInsDocs/Krejcieand Morgan.pdf pada tanggal 6 juni 2013.

Kunto, A.A. (1999). Remaja tentang Hedonisme : Kecil Bahagia, Muda Foya-Foya, Tua Kaya Raya, Mati Masuk Surga. Yogyakarta:PT. Kanisius Martha, Sri H., \& Imam S. (2008). Hubungan Antara Harga Diri dengan Kecenderungan Gaya Hidup Hedonis Pada Mahasiswi Universitas Diponegoro. Jurnal IImiah Psikologi. Diakses pada tanggal 25 november 2013 dari http://Psikohumanika. Se t i a budi . a c . id/i ndex. $\mathrm{ph}$ p ? o pt i o $\mathrm{n}=\mathrm{com}$. content $\&$ view $=$ articel\&id -115 hubun gan-antara-harga-diri-dengan-gayahidup-hedonis-mahasiswi-universitasDiponegoro\&catid=72: nomor12-mei-2008

Monks, F. J., Knoers, H.M.O., \& Haditomo, S.R. (1998). Psikologi Perkembangan: Pengantar dalam Berbagai Bagiannya. Yogyakarta : Gadjah Mada University Perss

Mulia, T. (2010). Hubungan Antara Tingkat Religiusitas Dengan Hedonisme Pada Remaja Akhir. Skripsi. Diterbitkan. Jakarta. Universitas Gunadarma. Diakses pada tanggal 23 April 2014 dari http:// I ibrary.gunadarma.ac.id/ repository/view/15458/ hubungan-antara tingkat-religiusitasd e ngan-hedon is m e - pad a $\mathrm{r}$ e $\mathrm{m}$ a j a - a k h i r. ht m l / Milfont, T. L., Andrade, P. R., Belo, R. P., \& Pessoa, V. S. (2008). Testing Zimbardo Time Perspective Inventory in a Brazilian sample. Interamerican Journal of Psychology, 42, 49-58.

Oktavia, T. (2013). Hubungan Antara Citra Tubuh dengan Pemberian ASI. Skripsi. Banda Aceh: Fakul- 
tas Psikologi Universitas Syiah Kuala. Santrock, J. W. (2003). Adolescence; Rocca, S. (2005). Religion and value systems. Journal of Social Issues, 61, 747-759.

Salam, B. (2002). Etika Individual : Pola Dasar Filsafat Moral. c. 1. Jakarta : Rineka Cipta Perkembangan remaja (terjemahan). Jakarta : Erlangga

Sarwono, W. S. (2006). Psikologi Remaja. Jakarta : Raja Grafindo Persada.

Thouless, R.H. (2000). Pengantar Psikologi Agama. Jakarta Rajawali Pers 